\title{
Development, Acceptance, and Concerns Surrounding App-Based Services to Overcome the COVID-19 Outbreak in South Korea: Web-Based Survey Study
}

Jihwan Park ${ }^{1}$, PhD; Jinhyun $\mathrm{Han}^{2}$, BA; Yerin $\mathrm{Kim}^{3}$; Mi Jung Rho ${ }^{2}, \mathrm{PhD}$

\footnotetext{
${ }^{1}$ School of Software Convergence, College of Software Convergence, Dankook University, Yongin-si, Republic of Korea

${ }^{2}$ Department of Urology, Seoul St. Mary's Hospital, College of Medicine, The Catholic University of Korea, Seoul, Republic of Korea

${ }^{3}$ Department of Korean Language and Literature, The Anyang University of Korea, Anyang-si, Republic of Korea
}

Corresponding Author:

Mi Jung Rho, PhD

Department of Urology, Seoul St. Mary's Hospital

College of Medicine

The Catholic University of Korea

222 Banpo-daero, Seocho-Gu

Seoul, 06591

Republic of Korea

Phone: 82222585905

Email: romy1018@naver.com

\section{Abstract}

Background: Since the COVID-19 outbreak, South Korea has been engaged in various efforts to overcome the pandemic. One of them is to provide app-based COVID-19-related services to the public. As the pandemic continues, a need for various apps has emerged, including COVID-19 apps that can support activities aimed at overcoming the COVID-19 pandemic.

Objective: We aimed to determine which apps were considered the most necessary according to users and evaluate the current status of the development of COVID-19-related apps in South Korea. We also aimed to determine users' acceptance and concerns related to using apps to support activities to combat COVID-19.

Methods: We collected data from 1148 users from a web-based survey conducted between November 11 and December 6, 2020. Basic statistical analysis, multiple response analysis, and the Wilcoxon rank sum test were performed using R software. We then manually classified the current status of the development of COVID-19-related apps.

Results: In total, 68.4\% (785/1148) of the respondents showed high willingness to protect themselves from COVID-19 by using related apps. Users considered the epidemiological investigation app to be the most necessary app (709/1148, 61.8\%) overall, followed by the self-management app for self-isolation (613/1148, 53.4\%), self-route management app (605/1148, 52.7\%), COVID-19 symptom management app (483/1148, 42.1\%), COVID-19-related information provision app (339/1148, 29.5\%), and mental health management app $(270 / 1148,23.5 \%)$. Despite the high intention to use these apps, users were also concerned about privacy issues and media exposure. Those who had an underlying disease and had experience using COVID-19-related apps showed significantly higher intentions to use those apps ( $P=.05$ and $P=.01$, respectively).

Conclusions: Targeting users is very important in order to design and develop the most necessary apps. Furthermore, to gain the public's trust and make the apps available to as many people as possible, it is vital to develop diverse apps in which privacy protection is maximized.

(JMIR Med Inform 2021;9(7):e29315) doi: 10.2196/29315

\section{KEYWORDS}

COVID-19; app-based services; acceptance; concerns; epidemiological investigation, self-route management app, privacy 


\section{Introduction}

\section{Background}

Since the outbreak of COVID-19, countries worldwide have been engaging in various efforts to overcome the challenges associated with it. One of these efforts include providing app-based services, such as COVID-19 contact tracing apps, to support activities aimed at combating COVID-19 [1-4].

South Korea has been integrating digital technology to make it applicable to all fields [5,6], including surveillance, testing, contact tracing, and self-isolation, as well as apps providing COVID-19-related information. Several COVID-19-related apps have been developed and are currently being used, including the Self-Quarantine Safety Protection app [7] and apps for COVID-19 symptom management app and self-isolation. These apps have greatly helped South Korea in responding to the COVID-19 crisis. However, as the COVID-19 pandemic continues, the need for more diverse apps is emerging, such as COVID-19 vaccine apps [8], epidemiological investigation apps, self-route management apps, and mental health management apps.

To support activities aimed at overcoming COVID-19, diverse apps need to be developed for specific purposes. It is also vital to ensure that the majority of people can be assisted through these apps. Therefore, to ensure the effectiveness of COVID-19-related apps, we need to learn more about the apps that people need, as well as their acceptance and concerns regarding using these apps, for example, concerns regarding security issues. However, although security and information protection issues may arise while developing and using these apps [5,9-11], the use of technology during COVID-19 has focused on using larger amounts of personal data to contain the spread of COVID-19 [12], rather than reflecting on users' intentions or concerns.
For COVID-19-related technologies to be effective, most people need to be able to use them. To achieve this, we need to focus on users' intentions and concerns, rather than adopting a technical approach [13]. Therefore, in this study, we aimed to determine the most necessary apps as preferred by users and identify the current status of the development of COVID-19-related apps in South Korea. Furthermore, we aimed to determine users' acceptance and concerns related to using apps to overcome the COVID-19 crisis.

\section{Current Status of Development of COVID-19-Related Apps in South Korea}

We organized various COVID-19-related apps developed in South Korea according to their release date (Table 1). Thus far, these apps can be classified according to the following main function types: (1) COVID-19-related information provision, (2) COVID-19 symptom management, (3) COVID-19 self-diagnosis, (4) self-route management, (5) mapping of COVID-19 cases, and (6) self-report of confirmed COVID-19 cases.

In early 2020, there were many apps providing COVID-19-related information, but over time, these evolved into COVID-19 symptom management and self-route management apps. Informational apps focus on providing information on the current status of COVID-19; subsequently, information relevant to the present state of COVID-19, such as information about masks and vaccines, is gradually updated and modified to remain relevant. For apps related to self-route management and mapping of COVID-19 cases, however, information is automatically saved using GPS or a QR code. Furthermore, these apps feature a function notifying users of the risk rate, such as mapping confirmed persons with COVID-19. Detailed information about the apps can be found in Table S1 of Multimedia Appendix 1. 
Table 1. COVID-19-related apps and app functions in South Korea.

\begin{tabular}{|c|c|c|c|c|c|c|c|c|c|}
\hline \multirow[t]{2}{*}{ No. } & \multirow[t]{2}{*}{ Release date } & \multirow[t]{2}{*}{ App name } & \multicolumn{6}{|c|}{ Functions of COVID-19-related apps } & \multirow[t]{2}{*}{ OS } \\
\hline & & & $\begin{array}{l}\text { Information } \\
\text { provision }\end{array}$ & $\begin{array}{l}\text { Symptom } \\
\text { manage- } \\
\text { ment }\end{array}$ & $\begin{array}{l}\text { Self-diag- } \\
\text { nosis }\end{array}$ & $\begin{array}{l}\text { Self-route } \\
\text { manage- } \\
\text { ment }\end{array}$ & $\begin{array}{l}\text { Mapping } \\
\text { of cases }\end{array}$ & $\begin{array}{l}\text { Self-report } \\
\text { of confirmed } \\
\text { cases }\end{array}$ & \\
\hline 1 & February 2020 & CORNANOW & $\checkmark$ & & & & & & Android \\
\hline 2 & $\begin{array}{l}\text { February } 7 \\
2020\end{array}$ & $\begin{array}{l}\text { Corona Explorer } \\
\text { (코로나 탐색기) }\end{array}$ & $\checkmark$ & & & & & & Android \\
\hline 3 & $\begin{array}{l}\text { February 17, } \\
2020\end{array}$ & Corona App (코로나앱) & $\checkmark$ & & & & & & Android \\
\hline 4 & $\begin{array}{l}\text { February 25, } \\
2020\end{array}$ & $\begin{array}{l}\text { Corona contact test } \\
\text { (코로나 접촉검사) }\end{array}$ & & & & & $\checkmark$ & & Android \\
\hline 5 & $\begin{array}{l}\text { February 26, } \\
2020\end{array}$ & $\begin{array}{l}\text { Corona } 19 \text { situation board (코로 } \\
\text { 나19 상황판) }\end{array}$ & $\checkmark$ & & & & & & Android \\
\hline 6 & March 2, 2020 & $\begin{array}{l}\text { Corona } 19 \text { status board } \\
\text { (코로나19 현황판) }\end{array}$ & $\checkmark$ & & & & & & Android \\
\hline 7 & March 6, 2020 & $\begin{array}{l}\text { Corona } 19 \text { Gyeongnam (코로나19 } \\
\text { 경남) }\end{array}$ & $\checkmark$ & & & & & & Android \\
\hline 8 & March 6, 2020 & $\begin{array}{l}\text { Corona compass } \\
\text { (코로나침반) }\end{array}$ & $\checkmark$ & & & & $\checkmark$ & & Android \\
\hline 9 & March 6, 2020 & Corona Map (코로나맵) & $\checkmark$ & & & & & & Android \\
\hline 10 & March 9, 2020 & Wear mask (웨어마스크) & $\checkmark$ & & & & & & Android \\
\hline 11 & March 9, 2020 & $\begin{array}{l}\text { Corona } 19 \text { news delivery } \\
\text { (코로나19 소식전달) }\end{array}$ & $\checkmark$ & & & & & & Android \\
\hline 12 & March 10, 2020 & $\begin{array}{l}\text { Corona pin } \\
\text { (코로나핀) }\end{array}$ & $\checkmark$ & & & & & & Android \\
\hline 13 & March 11, 2020 & $\begin{array}{l}\text { Coronaga } \\
\text { (코로나가) }\end{array}$ & & & & & $\checkmark$ & & Android \\
\hline 14 & March 11, 2020 & NEAR & $\checkmark$ & & & & & & Android \\
\hline 15 & March 12, 2020 & $\begin{array}{l}\text { Corona Map Wiki } \\
\text { (코로나맵위키) }\end{array}$ & $\checkmark$ & & & & & & Android \\
\hline 16 & March 12, 2020 & Carrot Mask & $\checkmark$ & & & & & & Android \\
\hline 17 & March 18, 2020 & Mark (마크) & $\checkmark$ & & & & & & Android \\
\hline 18 & March 18, 2020 & Coback Plus (코백플러스) & $\checkmark$ & & & & & & Android \\
\hline 19 & March 20, 2020 & $\begin{array}{l}\text { Where is the mask (마스크어덨 } \\
\text { 니) }\end{array}$ & $\checkmark$ & & & & & & Android \\
\hline 20 & March 20, 2020 & Mask time (마스크타임) & $\checkmark$ & & & & & & Android \\
\hline 21 & March 20, 2020 & Let me know (알려줘) & $\checkmark$ & & & & & & Android \\
\hline 22 & March 30, 2020 & $\begin{array}{l}\text { Corona } 19 \text { self-diagnosis (코로나 } \\
19 \text { 자가진단) }\end{array}$ & & & $\checkmark$ & & & & Android \\
\hline 23 & April 2020 & $\begin{array}{l}\text { BMC Corona } 19 \text { employee } \\
\text { guardian } \\
\text { BMC (코로나19 직원지킴이) }\end{array}$ & & $\checkmark$ & & & & & $\begin{array}{l}\text { An- } \\
\text { droid, } \\
\text { iOS }\end{array}$ \\
\hline 24 & April 2020 & $\begin{array}{l}\text { Search for COVID-19 guidelines } \\
\text { (코로나19 지침 검색) }\end{array}$ & $\checkmark$ & & & & & & $\begin{array}{l}\text { An- } \\
\text { droid, } \\
\text { iOS }\end{array}$ \\
\hline 25 & April 6, 2020 & Corona World (코로나월드) & $\checkmark$ & & & & & & Android \\
\hline 26 & May 22, 2020 & JINOSYS & $\checkmark$ & & & $\checkmark$ & & & Android \\
\hline
\end{tabular}




\begin{tabular}{|c|c|c|c|c|c|c|c|c|c|}
\hline \multirow[t]{2}{*}{ No. } & \multirow[t]{2}{*}{ Release date } & \multirow[t]{2}{*}{ App name } & \multicolumn{6}{|c|}{ Functions of COVID-19-related apps } & \multirow[t]{2}{*}{ OS } \\
\hline & & & $\begin{array}{l}\text { Information } \\
\text { provision }\end{array}$ & $\begin{array}{l}\text { Symptom } \\
\text { manage- } \\
\text { ment }\end{array}$ & $\begin{array}{l}\text { Self-diag- } \\
\text { nosis }\end{array}$ & $\begin{array}{l}\text { Self-route } \\
\text { manage- } \\
\text { ment }\end{array}$ & $\begin{array}{l}\text { Mapping } \\
\text { of cases }\end{array}$ & $\begin{array}{l}\text { Self-report } \\
\text { of confirmed } \\
\text { cases }\end{array}$ & \\
\hline 27 & June 2020 & $\begin{array}{l}\text { Incheon } \\
\text { Corona } 19 \text { freeze } \\
\text { (인천 코로나19 꼼작마!) }\end{array}$ & $\checkmark$ & $\checkmark$ & & $\checkmark$ & & & $\begin{array}{l}\text { An- } \\
\text { droid, } \\
\text { iOS }\end{array}$ \\
\hline 28 & June 2, 2020 & $\begin{array}{l}\text { School safety guard } \\
\text { (학교 안전지킴이) }\end{array}$ & & $\checkmark$ & & & & & Android \\
\hline 29 & July 13,2020 & Corona Memo (코로나메모) & & & & $\checkmark$ & & & Android \\
\hline 30 & August 2020 & FAMY 2.0 & & & & $\checkmark$ & & & Android \\
\hline 31 & August 7, 2020 & Corona index (코로나지수) & $\checkmark$ & & & & & & Android \\
\hline 32 & $\begin{array}{l}\text { August 10, } \\
2020\end{array}$ & Corona Pass (코로나패스) & & & & $\checkmark$ & & & Android \\
\hline 33 & $\begin{array}{l}\text { August 31, } \\
2020\end{array}$ & $\begin{array}{l}\text { Corona detector } \\
\text { (코로나 탐지기) }\end{array}$ & & & & & $\checkmark$ & & Android \\
\hline 34 & $\begin{array}{l}\text { September 8, } \\
2020\end{array}$ & KFKOREA & $\checkmark$ & & & & & & Android \\
\hline 35 & $\begin{array}{l}\text { September 11, } \\
2020\end{array}$ & $\begin{array}{l}\text { Corona location tracking (코로나 } \\
\text { 위치추적) }\end{array}$ & & & & $\checkmark$ & & & Android \\
\hline 36 & October 6, 2020 & Avoiding corona (코로나피하go) & $\checkmark$ & & & $\checkmark$ & & & Android \\
\hline 37 & $\begin{array}{l}\text { October } 12, \\
2020\end{array}$ & Koala & $\checkmark$ & & & $\checkmark$ & & & Android \\
\hline 38 & $\begin{array}{l}\text { December } 1, \\
2020\end{array}$ & Corona Alert (코로나알리미) & $\checkmark$ & & & & & & Android \\
\hline 39 & $\begin{array}{l}\text { December 11, } \\
2020\end{array}$ & COVID SHIELD & $\checkmark$ & & & & & & Android \\
\hline 40 & $\begin{array}{l}\text { December 23, } \\
2020\end{array}$ & Corona Safer & $\checkmark$ & & & $\checkmark$ & $\checkmark$ & & Android \\
\hline 41 & January 6, 2021 & Hanyang Univ. & & & & $\checkmark$ & & $\checkmark$ & Android \\
\hline & & $\begin{array}{l}\text { Corona contact tracking app (코로 } \\
\text { 나 접촉 추적앱) }\end{array}$ & & & & & & & \\
\hline 42 & $\begin{array}{l}\text { January } 28, \\
2021\end{array}$ & $\begin{array}{l}\text { Corona traffic light (코로나 신호 } \\
\text { 등) }\end{array}$ & $\checkmark$ & & & & & & Android \\
\hline 43 & $\begin{array}{l}\text { February } 3, \\
2021\end{array}$ & $\begin{array}{l}\text { Corona } 19 \text { vaccine reminder (코로 } \\
\text { 나19 백신 알리미) }\end{array}$ & $\checkmark$ & $\checkmark$ & & & & & Android \\
\hline 44 & $\begin{array}{l}\text { February } 8, \\
2021\end{array}$ & $\begin{array}{l}\text { All about the corona status (코현 } \\
\text { 모) }\end{array}$ & $\checkmark$ & & & & & & Android \\
\hline 45 & $\begin{array}{l}\text { February } 9 \\
2021\end{array}$ & $\begin{array}{l}\text { Corona traffic safety (코로나 동 } \\
\text { 선 안심이) }\end{array}$ & & & & $\checkmark$ & & & $\begin{array}{l}\text { An- } \\
\text { droid, } \\
\text { iOS }\end{array}$ \\
\hline 46 & $\begin{array}{l}\text { February } 16, \\
2021\end{array}$ & Corona magnifier (코로나돋보기) & $\checkmark$ & & & & & & Android \\
\hline 47 & March 3, 2021 & Corona bored (코로나지겹다) & $\checkmark$ & & & & & & Android \\
\hline 48 & March 22, 2021 & $\begin{array}{l}\text { Corona vaccine reminder (코브리 } \\
\text { 움) }\end{array}$ & $\checkmark$ & & & & & & Android \\
\hline
\end{tabular}

\section{Methods}

\section{Study Sample}

We conducted a web-based survey between November 11 and December 6, 2020. The number of confirmed COVID-19 cases during the survey period ranged from 143 (on November 11) to 631 (on December 6). On November 1, 2020, the Korean government announced a plan to reorganize social distancing measures by subdividing social distancing into three to five stages; this came into effect on November 7, 2020. Thus, during 
the survey period, social distancing levels ranged from stage 1 to stage 2, based on the five stages of social distancing [14].

We had limitations in conducting a survey that included the total Korean population. Therefore, the survey was conducted keeping in mind the cost and time of distributing the questionnaire. In South Korea, as of December 6, 2020, Seoul, Gyeonggi-do, Incheon, and Daegu had the highest number of COVID-19 cases nationwide, accounting for $79 \%$ of all COVID-19 cases in South Korea [15].

We posted the survey recruitment notice on bulletin boards of online cafes, such as Korean portal online cafes (NAVER) [16], as well as university and college student community bulletin boards. In addition, a questionnaire was also distributed through referrals from cafe users. A total of 1170 people responded. After duplicate and incorrect responses were excluded, 1148 valid, completed questionnaires were obtained. The survey ended on December 6, where the proportion of survey respondents by region was similar to the proportion of COVID-19 cases by region as of December 6 .

\section{Review of COVID-19-Related Apps and Functions Developed in South Korea}

To determine the current status of apps developed in South Korea, we conducted a search on application software downloading services such as the Apple App Store, Google Play Store, and Naver One Store. We aimed to find all COVID-19-related apps developed after January 2020, that is, after the COVID-19 outbreak was reported. We used keywords such as "COVID," "COVID-19," "Corona," "Corona 19," and "infectious disease." We excluded COVID-19-related apps developed by the Ministry of the Interior and Safety and the Ministry of Health and Welfare. Thus, we found a total of 54 apps. Among these, overseas apps and apps introduced before the COVID-19 outbreak were excluded. For the remaining 48 apps, two medical informatics professors (JP and MJR) and two researchers ( $\mathrm{JH}$ and $\mathrm{YK}$ ) manually organized the app features into categories (described below) over four meetings.

To categorize these apps, it was necessary to largely classify them by app features. However, there was no clear criteria for categorizing the app functions. Based on previous studies $[12,17,18]$, we classified the apps developed in South Korea thus far into the following main function types to determine their current status: (1) COVID-19-related information provision, (2) COVID-19 symptom management, (3) COVID-19 self-diagnosis, (4) self-route management, (5) mapping of COVID-19 cases, and (6) self-report of COVID-19 confirmed cases.

\section{The Intention to Use COVID-19-Related Apps}

We developed a questionnaire determining the intention to use COVID-19-related apps based on previous studies [19,20]. Intention to use is the most frequently used variable in research on technology acceptance and is widely used in the health care field [21,22]. Additionally, the questionnaire items were modified for this study. That is, "intention to use" was defined as the degree to which a user's behavioral intention indicated their willingness to use COVID-19-related apps. Responses were given on a 5-point Likert scale ranging from $1=$ "very unwilling" to $5=$ "very willing."

\section{Searches of App-Based Services to Support Activities to Combat COVID-19}

COVID-19-related apps that were currently deemed as necessary were selected based on the six abovementioned functions. However, we added additional apps, namely the epidemiological investigation app, self-management app for self-isolation, and mental health management app.

Finally, we classified app-based services to support activities to overcome the COVID-19 crisis according to six app types: (1) epidemiological investigation apps, (2) self-management apps for self-isolation, (3) self-route management app, (4) COVID-19 symptom management app, (5) COVID-19-related information provision app, and (6) mental health management app.

\section{Statistical Analysis}

The question asking participants which app services are needed to support activities aimed at overcoming the COVID-19 crisis was a multiple-response question; thus, multiple response analysis was used. The Wilcoxon rank sum test [23] was used to analyze people's intention to use app-based services required to overcome COVID-19. Basic statistical analysis, multiple response analysis, and Wilcoxon rank sum test were conducted using R software (version 3.6.1). Furthermore, we manually classified the current status of the development of COVID-19-related apps.

\section{Ethics}

The study procedures were carried out in accordance with the Declaration of Helsinki and were approved by the Institutional Review Board of Catholic University (MC20QISI0125). Participants' data were anonymized to ensure confidentiality was maintained.

\section{Results}

\section{Participants' Characteristics}

Of the total 1148 respondents, $675(58.8 \%)$ were female and the majority $(n=475,41.4 \%)$ were in their 30 s (Table 2$)$. The proportion of married respondents was 50.6\% (581/1148). Furthermore; $846(73.7 \%)$ of the respondents had a university degree or higher; 592 (51.6\%) were employed in professional, managerial, and white-collar jobs; and 128 (11.1\%) were medical staff. Moreover, $883(76.9 \%)$ respondents lived in Seoul, Gyeonggi-do, Incheon, and Daegu. 
Table 2. Demographic characteristics $(\mathrm{N}=1148)$.

\begin{tabular}{|c|c|}
\hline Characteristic & Participants, n (\%) \\
\hline \multicolumn{2}{|l|}{ Gender } \\
\hline Male & $473(41.2)$ \\
\hline Female & $675(58.8)$ \\
\hline \multicolumn{2}{|l|}{ Age } \\
\hline 18 and 19 & $14(1.2)$ \\
\hline $20-29$ & $342(29.8)$ \\
\hline $30-39$ & $475(41.4)$ \\
\hline $40-49$ & $238(20.7)$ \\
\hline$>50$ & $79(6.9)$ \\
\hline \multicolumn{2}{|l|}{ Marital status } \\
\hline Single & $551(48)$ \\
\hline Married & $581(50.6)$ \\
\hline Other (including divorced, separated, or widowed) & $16(1.4)$ \\
\hline \multicolumn{2}{|l|}{ Education } \\
\hline High school graduation or lower & $93(8.1)$ \\
\hline College students & $209(18.2)$ \\
\hline University graduation or higher & $846(73.7)$ \\
\hline \multicolumn{2}{|l|}{ Occupation } \\
\hline Other or unemployed & $56(4.9)$ \\
\hline Service, sales, or production & $96(8.4)$ \\
\hline Self-employed or freelancer & $98(8.5)$ \\
\hline Office worker, professional, or administrative job & $592(51.6)$ \\
\hline Housewife & $133(11.6)$ \\
\hline Student & $173(15.1)$ \\
\hline \multicolumn{2}{|l|}{ Medical profession } \\
\hline No & $1020(88.9)$ \\
\hline Yes & $128(11.1)$ \\
\hline \multicolumn{2}{|l|}{ Salary $(\text { US \$) })^{\mathbf{a}}$} \\
\hline$<1825.82$ & $73(6.4)$ \\
\hline $1825.82-3,651.63$ & $426(37.1)$ \\
\hline $3,651.63-5,477.45$ & $330(28.7)$ \\
\hline$>5,477.45$ & $319(27.8)$ \\
\hline \multicolumn{2}{|l|}{ Location } \\
\hline Seoul & $420(36.6)$ \\
\hline Gyeonggi-do & $299(26)$ \\
\hline Daegu Metropolitan City & $103(9)$ \\
\hline Incheon Metropolitan City & $61(5.3)$ \\
\hline Daejeon & $57(5)$ \\
\hline Busan & $51(4.4)$ \\
\hline Gyeongsangbuk-do & $29(2.5)$ \\
\hline Chungcheongnam-do & $25(2.2)$ \\
\hline Gwangju & $21(1.8)$ \\
\hline
\end{tabular}




\begin{tabular}{ll}
\hline Characteristic & Participants, $\mathrm{n}(\%)$ \\
\hline Ulsan Metropolitan City & $17(1.5)$ \\
Gyeongsangnam-do & $15(1.3)$ \\
Gangwon-do & $13(1.1)$ \\
Jeollabuk do & $13(1.1)$ \\
Chung-cheong bukdo & $10(0.9)$ \\
Sejong City & $7(0.6)$ \\
Jeju Special Self-Governing Province & $4(0.3)$ \\
Jeollanam-do & $3(0.3)$ \\
\hline
\end{tabular}

${ }^{a}$ A currency exchange rate of US $\$ 1=W 1095.40$ is applicable (buy and sell base rate on January 13,2021 ).

\section{COVID-19-Related Characteristics}

Among the 1148 respondents, 95 (8.3\%) had an underlying disease, such as high blood pressure, diabetes, asthma, kidney failure, or tuberculosis; $91(7.9 \%)$ had experienced self-isolation due to COVID-19; 174 (15.2\%) had experience with COVID-19 testing; 4 (0.3\%) were confirmed COVID-19 cases; $78(6.8 \%)$ had a family member or friend with COVID-19; $362(31.5 \%)$ reported that they had jobs that were easily exposed to COVID-19; and 889 (77.4\%) thought that their company was satisfactorily dealing with COVID-19 quarantine measures. Finally, 219 (19.1\%) of the respondents had experience using COVID-19-related apps.

\section{Intention to Use COVID-19-Related Apps}

This study assessed participants' willingness to use COVID-19-related apps as shown in Figure 1. The first question asked the 1148 respondents if they were willing to protect themselves from COVID-19 by using COVID-19-related health care apps (Table 3), to which $68.4 \%(n=785)$ reported that they were "willing" or "very willing." The second question asked the respondents whether they wanted to be monitored through a COVID-19 management app, to with $47.6 \%(n=546)$ of the respondents reporting that they wanted to be monitored. However, $35.4 \%(n=406)$ of the respondents had a neutral opinion about this. The last question asked respondents if they wanted to be protected through a COVID-19 management app; $51 \%(\mathrm{n}=586)$ of the respondents wanted to be protected through a COVID-19 management app, whereas $32.9 \%(n=378)$ had a neutral opinion.

Figure 1. Intention to use COVID-19-related apps among survey respondents (N=1148).
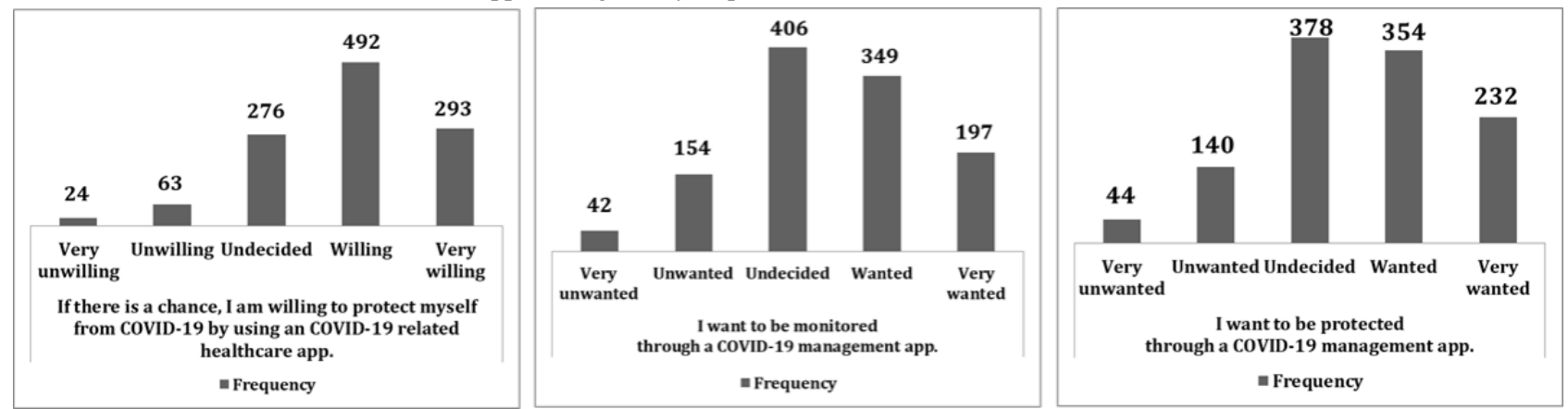
Table 3. Respondents' ( $\mathrm{N}=1148$ ) intention to use COVID-19-related apps and the epidemiological investigation app.

\begin{tabular}{|c|c|}
\hline Questions and intention to use the app & Participants, n (\%) \\
\hline \multicolumn{2}{|l|}{ COVID-19-related apps } \\
\hline \multicolumn{2}{|c|}{ If one is available, I am willing to protect myself from COVID-19 by using a COVID-19-related health care app. } \\
\hline Very unwilling & $24(2.1)$ \\
\hline Unwilling & $63(5.5)$ \\
\hline Undecided & $276(24.0)$ \\
\hline Willing & $492(42.9)$ \\
\hline Very willing & $293(25.5)$ \\
\hline \multicolumn{2}{|c|}{ I want to be monitored through a COVID-19 management app. } \\
\hline Very unwanted & $42(3.7)$ \\
\hline Unwanted & $154(13.4)$ \\
\hline Undecided & $406(35.4)$ \\
\hline Wanted & $349(30.4)$ \\
\hline Very wanted & $197(17.2)$ \\
\hline \multicolumn{2}{|c|}{ I want to be protected through a COVID-19 management app. } \\
\hline Very unwanted & $44(3.8)$ \\
\hline Unwanted & $140(12.2)$ \\
\hline Undecided & $378(32.9)$ \\
\hline Wanted & $354(30.8)$ \\
\hline Very wanted & $232(20.2)$ \\
\hline \multicolumn{2}{|l|}{ Epidemiological investigation app } \\
\hline \multicolumn{2}{|c|}{ Are you willing to use the epidemiological investigation app? } \\
\hline Very unwilling & $19(1.7)$ \\
\hline Unwilling & $41(3.6)$ \\
\hline Undecided & $238(20.7)$ \\
\hline Willing & $554(48.3)$ \\
\hline Very willing & $296(25.8)$ \\
\hline
\end{tabular}

\section{App-Based Services to Support Activities to Overcome COVID-19}

We surveyed which app-based services were needed to support activities aimed at overcoming COVID-19; this was a multiple-response question. Of the 1148 respondents, 709 $(61.8 \%)$ reported that the epidemiological investigation app was the most necessary service (Table 4). In addition, respondents stated that a self-management app for self-isolation $(613 / 1148$, $53.4 \%)$, preventive self-route management app (605/1148, 52.7\%), COVID-19 symptom management app (483/1148, $42.1 \%)$, and COVID-19-related information provision app $(339 / 1148,29.5 \%)$ were needed. The lowest percentage of responses $(270 / 1148,23.5 \%)$ received were regarding the use of mental health management apps. 
Table 4. App-based services needed to support activities to overcome COVID-19.

\begin{tabular}{|c|c|c|}
\hline \multirow[t]{2}{*}{ Question and responses } & \multicolumn{2}{|l|}{ Value } \\
\hline & Responses, $\mathrm{n}(\%)(\mathrm{n}=3019)$ & Participants, $\mathrm{n}(\%)(\mathrm{N}=1148)$ \\
\hline \multicolumn{3}{|c|}{ Which app-based services are needed to overcome COVID-19? } \\
\hline Epidemiological investigation app & $709(23.5)$ & 709 (61.8) \\
\hline Self-management app for self-isolation & $613(20.3)$ & $613(53.4)$ \\
\hline Self-route management app & $605(20)$ & $605(52.7)$ \\
\hline COVID-19 symptom management app & $483(16)$ & $483(42.1)$ \\
\hline COVID-19-related information provision app & $339(11.2)$ & $339(29.5)$ \\
\hline Mental health management apps & $270(8.9)$ & $270(23.5)$ \\
\hline
\end{tabular}

\section{Intention to Use and Reasons for Reluctance to Use the Epidemiological Investigations App}

First, we inquired whether the respondents were willing to use the epidemiological investigation app, which was reported as the most necessary service. In total, 554 of the 1148 (48.3\%) respondents reported that they would use this app, with 296 $(25.8 \%)$ indicating that they were very willing (Figure 2 and Table 3).

Figure 2. Willingness to use the epidemiological investigation app ( $\mathrm{N}=1148)$.

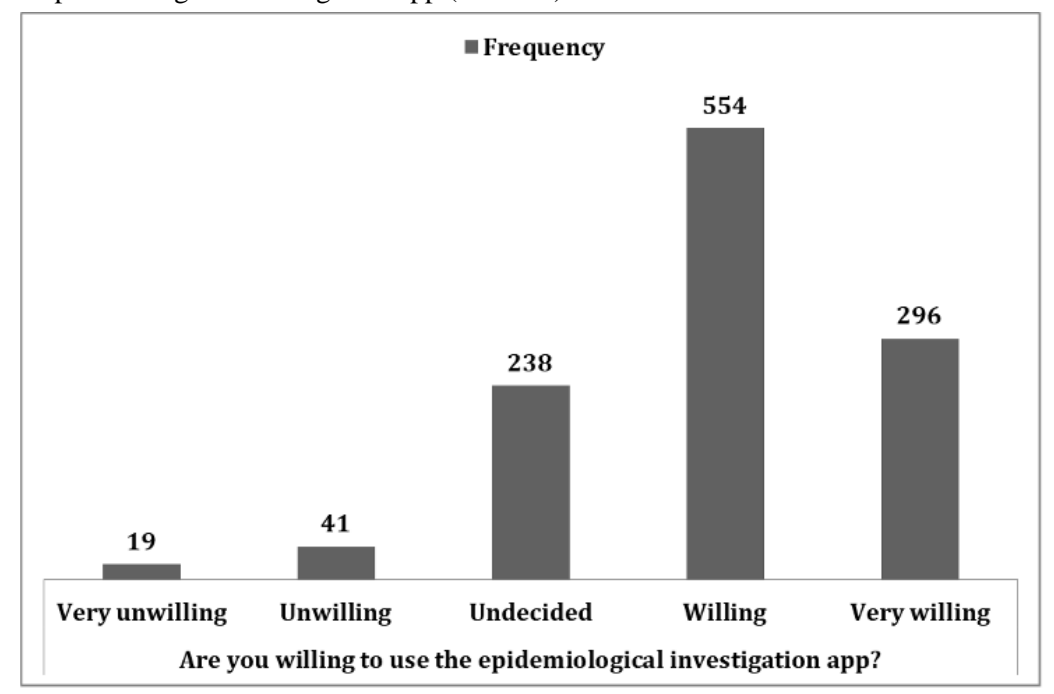

Table 5. Reasons for reluctance to use the epidemiological investigation app (N=1148).

\begin{tabular}{ll}
\hline Question and responses & \multicolumn{1}{l}{ Participants, $\mathrm{n}(\%)$} \\
\hline If you are reluctant to use the epidemiological investigation app, why? & \\
Privacy invasion problem & $480(41.8)$ \\
Personal information exposure and media exposure & $449(39.1)$ \\
Criticism and reproach of others & $4(0.3)$ \\
Not reluctant & $13(1.1)$ \\
No reason & $202(17.6)$ \\
\hline
\end{tabular}

\section{Intention to Use App-Based Services Required to Overcome the COVID-19 Crisis}

The intention to use app-based services required to overcome COVID-19 were compared using the Wilcoxon rank sum test. The various app-based services evaluated in this study were as
Second, we inquired why they were reluctant to use the app. Regarding this, of the 1148 respondents, 480 (41.8\%) of respondents cited privacy concerns, 449 (39.1\%) expressed concerns about personal information exposure and media disclosure, and 202 (17.6\%) did not have a reason (Table 5). The response rate of those who were not reluctant was very low $(13 / 1148,1.1 \%)$.

follows: (1) epidemiological investigation app, (2) self-management app for self-isolation, (3) self-route management app, and (4) COVID-19 symptom management app. The results indicated whether there were any differences in the intention to use these four apps according to the COVID-19-related characteristics of the respondents. These 
characteristics included the following: (1) presence of an underlying disease, (2) self-isolation experience, (3) COVID-19 test experience, (4) confirmed COVID-19 cases, (5) family members or friends with a confirmed COVID-19 case, (6) occupations that are easily exposed to COVID-19, (7) a company with good COVID-19 prevention strategies, and (8) experience with COVID-19-related apps (Table 6).
Regarding the presence of underlying disease and COVID-19-related app experience, there were significant differences in respondents' intention to use the epidemiological investigation app, self-management app for self-isolation, self-route management app, and COVID-19 symptom management app. Moreover, those who had an underlying disease and had experience using COVID-19-related apps showed significantly higher intention to use these four apps $(P=.05$ and $P=.01$, respectively; Table 6). 
Table 6. COVID-19-related characteristics and intention to use apps among survey participants $(\mathrm{N}=1148)$.

\begin{tabular}{|c|c|c|c|c|c|c|c|c|c|}
\hline \multirow[t]{2}{*}{$\begin{array}{l}\text { Variable and in- } \\
\text { tention to use app }\end{array}$} & \multirow[t]{2}{*}{ Participants, n (\%) } & \multicolumn{2}{|c|}{$\begin{array}{l}\text { Epidemiological investi- } \\
\text { gation app }\end{array}$} & \multicolumn{2}{|c|}{$\begin{array}{l}\text { Self-management app for } \\
\text { self-isolation }\end{array}$} & \multicolumn{2}{|c|}{$\begin{array}{l}\text { Self-route management } \\
\text { app }\end{array}$} & \multicolumn{2}{|c|}{$\begin{array}{l}\text { COVID-19 symptom } \\
\text { management app }\end{array}$} \\
\hline & & $\operatorname{Mean}^{\mathrm{a}}(\mathrm{SD})$ & $P$ value & Mean (SD) & $P$ value & Mean (SD) & $P$ value & Mean (SD) & $P$ value \\
\hline \multicolumn{10}{|c|}{ Presence of underlying disease } \\
\hline No & $1053(91.7)$ & $\begin{array}{l}3.908 \\
(0.871)\end{array}$ & $.003^{\mathrm{b}}$ & $\begin{array}{l}3.944 \\
(0.871)\end{array}$ & .03 & $\begin{array}{l}3.816 \\
(0.900)\end{array}$ & .02 & $\begin{array}{l}3.885 \\
(0.899)\end{array}$ & .04 \\
\hline Yes & $95(8.3)$ & $\begin{array}{l}4.168 \\
(0.794)\end{array}$ & & $\begin{array}{l}4.158 \\
(0.719)\end{array}$ & & $\begin{array}{l}4.021 \\
(0.850)\end{array}$ & & $\begin{array}{l}4.095 \\
(0.787)\end{array}$ & \\
\hline \multicolumn{10}{|c|}{ Self-isolation experience } \\
\hline No & $1057(92.1)$ & $\begin{array}{l}3.923 \\
(0.868)\end{array}$ & .28 & $\begin{array}{l}3.953 \\
(0.869)\end{array}$ & .29 & $\begin{array}{l}3.836 \\
(0.898)\end{array}$ & .65 & $\begin{array}{l}3.900 \\
(0.896)\end{array}$ & .68 \\
\hline Yes & $91(7.9)$ & $\begin{array}{l}4.000 \\
(0.869)\end{array}$ & & $\begin{array}{l}4.066 \\
(0.757)\end{array}$ & & $\begin{array}{l}3.791 \\
(0.901)\end{array}$ & & $\begin{array}{l}3.934 \\
(0.854)\end{array}$ & \\
\hline \multicolumn{10}{|c|}{ COVID-19 test experience } \\
\hline No & $974(84.8)$ & $\begin{array}{l}3.941 \\
(0.842)\end{array}$ & .75 & $\begin{array}{l}3.977 \\
(0.841)\end{array}$ & .41 & $\begin{array}{l}3.857 \\
(0.857)\end{array}$ & .27 & $\begin{array}{l}3.912 \\
(0.868)\end{array}$ & .97 \\
\hline Yes & $174(15.2)$ & $\begin{array}{l}3.862 \\
(0.999)\end{array}$ & & $\begin{array}{l}3.874 \\
(0.965)\end{array}$ & & $\begin{array}{l}3.695 \\
(1.088)\end{array}$ & & $\begin{array}{l}3.851 \\
(1.020)\end{array}$ & \\
\hline \multicolumn{10}{|c|}{ COVID-19 confirmed person } \\
\hline No & 1144 (99.7) & $\begin{array}{l}3.929 \\
(0.868)\end{array}$ & .96 & $\begin{array}{l}3.960 \\
(0.860)\end{array}$ & .17 & $\begin{array}{l}3.836 \\
(0.895)\end{array}$ & .12 & $\begin{array}{l}3.904 \\
(0.892)\end{array}$ & .26 \\
\hline Yes & $4(0.3)$ & $\begin{array}{l}4.000 \\
(0.816)\end{array}$ & & $\begin{array}{l}4.500 \\
(1.000)\end{array}$ & & $\begin{array}{l}3.000 \\
(1.414)\end{array}$ & & $\begin{array}{l}3.500 \\
(1.000)\end{array}$ & \\
\hline \multicolumn{10}{|c|}{ Family or friends with confirmed COVID-19 } \\
\hline No & $1070(93.2)$ & $\begin{array}{l}3.937 \\
(0.851)\end{array}$ & .72 & $\begin{array}{l}3.959 \\
(0.858)\end{array}$ & .49 & $\begin{array}{l}3.823 \\
(0.900)\end{array}$ & .15 & $\begin{array}{l}3.901 \\
(0.891)\end{array}$ & .71 \\
\hline Yes & $78(6.8)$ & $\begin{array}{l}3.821 \\
(1.066)\end{array}$ & & $\begin{array}{l}4.000 \\
(0.912)\end{array}$ & & $\begin{array}{l}3.962 \\
(0.860)\end{array}$ & & $\begin{array}{l}3.923 \\
(0.908)\end{array}$ & \\
\hline \multicolumn{10}{|c|}{ Occupations that are easily exposed to COVID-19 } \\
\hline No & $786(68.5)$ & $\begin{array}{l}3.926 \\
(0.852)\end{array}$ & .55 & $\begin{array}{l}3.961 \\
(0.844)\end{array}$ & .64 & $\begin{array}{l}3.836 \\
(0.867)\end{array}$ & .63 & $\begin{array}{l}3.912 \\
(0.851)\end{array}$ & .91 \\
\hline Yes & $362(31.5)$ & $\begin{array}{l}3.936 \\
(0.902)\end{array}$ & & $\begin{array}{l}3.964 \\
(0.897)\end{array}$ & & $\begin{array}{l}3.826 \\
(0.962)\end{array}$ & & $\begin{array}{l}3.881 \\
(0.976)\end{array}$ & \\
\hline \multicolumn{10}{|c|}{ A company with good COVID-19 prevention } \\
\hline No & $259(22.6)$ & $\begin{array}{l}3.950 \\
(0.841)\end{array}$ & .74 & $\begin{array}{l}4.042 \\
(0.813)\end{array}$ & .11 & $\begin{array}{l}3.876 \\
(0.797)\end{array}$ & .58 & $\begin{array}{l}3.969 \\
(0.830)\end{array}$ & .23 \\
\hline Yes & $889(77.4)$ & $\begin{array}{l}3.924 \\
(0.876)\end{array}$ & & $\begin{array}{l}3.938 \\
(0.874)\end{array}$ & & $\begin{array}{l}3.820 \\
(0.925)\end{array}$ & & $\begin{array}{l}3.883 \\
(0.909)\end{array}$ & \\
\hline \multicolumn{10}{|c|}{ COVID-19-related app experience } \\
\hline No & $929(80.9)$ & $\begin{array}{l}3.896 \\
(0.876)\end{array}$ & .004 & $\begin{array}{l}3.931 \\
(0.877)\end{array}$ & .02 & $\begin{array}{l}3.799 \\
(0.895)\end{array}$ & .002 & $\begin{array}{l}3.875 \\
(0.896)\end{array}$ & .02 \\
\hline Yes & $219(19.1)$ & $\begin{array}{l}4.073 \\
(0.815)\end{array}$ & & $\begin{array}{l}4.091 \\
(0.779)\end{array}$ & & $\begin{array}{l}3.977 \\
(0.896)\end{array}$ & & $\begin{array}{l}4.018 \\
(0.867)\end{array}$ & \\
\hline
\end{tabular}

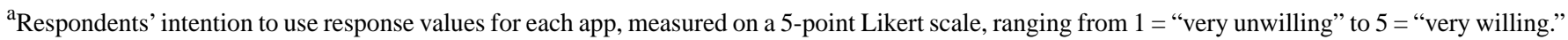
${ }^{\mathrm{b}}$ Italicized values indicate statistical significance. 


\section{Discussion}

This study aimed to determine the most essential apps required to overcome COVID-19 and the current status of the development of COVID-19-related apps in South Korea. Furthermore, this study aimed to determine users' acceptance of and concerns related to the use of these apps.

First, respondents expressed a high level of willingness to use COVID-19-related apps. Many respondents indicated that they wanted to be protected and monitored by using COVID-19-related apps. However, many also had a neutral opinion. Thus, these apps need to be developed in a way to gain the trust of prospective users

Second, the need to develop multiple apps emerged, which included epidemiological investigation apps, self-management apps for self-isolation, self-route management apps, COVID-19 symptom management apps (42\%), and mental health management apps. Most of the respondents $(61.8 \%)$ considered the epidemiological investigation app as the most needed app. In addition, the self-management app for self-isolation (53.4\%), self-route management app (52.7\%), COVID-19 symptom management app (42.1\%), and mental health management app $(23.5 \%)$ were marked as important, in that order.

In South Korea, there exists a self-management app for self-isolation, called "Self-quarantine Safety Protection App" $[7,24]$. However, based on the survey responses, it appears that various apps for self-management need to be developed. Regarding the self-route management app, apps using GPS and QR are increasingly being released; nevertheless, more apps are needed since their important continues to increase. To illustrate, the symptom management app helps identify new symptoms of COVID-19 and estimates the predicted value of specific symptoms [25]. In addition, these apps appear to be helpful in developing reliable screening tools. Thus, it is important to develop and utilize symptom management apps that can be used by the general public. Moreover, it was confirmed that there is also a demand for an app that can manage fatigue, mental health, and symptoms such as depression and anxiety caused by working from home and COVID-19 itself. There is ongoing research about COVID-19 survivors [26] and mental illness issues such as depression and anxiety caused by COVID-19 [27-29]. It has been reported that some people experienced worsened mental health after the pandemic [30]. This problem also applies to the medical staff such as physicians and nurses [31-33]. Therefore, active participation from the private sector and government is required to overcome the challenges posed by COVID-19. Furthermore, mental health problems need to be urgently addressed for groups such as COVID-19 survivors, medical staff, and women [29].

In the event of the COVID-19 pandemic, the main purpose of epidemiological investigations is to prevent early spread [34]; therefore, if the epidemiological investigation is delayed, secondary and tertiary disease transmission can occur, and people may become infected without knowing when or how they were infected. However, when a pandemic such as COVID-19 occurs, difficulties in epidemiological investigations and lack of workforce to conduct epidemiological investigation is often evident [35]. Therefore, there is also an urgent need to increase the number of epidemiological investigators, but this goal is difficult to achieve. To facilitate epidemiological investigations, a system that can actively cooperate with such investigations is needed. Consequently, if an epidemiological investigation app is developed, it can help actively provide basic information and medical records, including one's own movements, at the time of confirmation by the epidemiological investigator [36]. However, respondents expressed concern about infringement of personal information used by these services, such as COVID-19 contact tracing apps based on GPS or smartphone logs. Therefore, like the epidemiological investigation app, a self-route management app is also needed to reduce the fear of personal information infringement and increase the amount of information provided for epidemiological investigations.

Third, the importance of privacy invasion issues of COVID-19-related apps was emphasized in this study. Despite the high intention to use the epidemiological investigation app, people were very concerned about privacy invasion issues, personal information exposure, and media exposure. Thus, it is vital to consider how to resolve people's concerns about using these services, even after the necessary services are developed and available. Similarly, previous studies have found that people did not download and use contact tracing apps due to privacy concerns $[37,38]$. These findings suggest that it is important to design and develop apps deemed as necessary in order to overcome the COVID-19 crisis; however, to gain the public's trust and make such apps available to many people, minimum amounts of personal information should be used and seek the public interest based on this. In this regard, a service where users have authority over their information should be developed [39].

Fourth, we found that those who had an underlying disease and had experience using COVID-19-related apps showed a significantly higher intention to use apps such as the epidemiological investigation app, self-management app for self-isolation, self-route management app, and COVID-19 symptom management app. Interestingly, even if users reported self-isolation experiences, COVID-19 test experiences, COVID-19 confirmed experiences, and nearby confirmed cases, their willingness to use COVID-19-related apps was not higher. In addition, no differences were found between the intention to use the apps among respondents engaged in occupations that had a relatively high exposure to COVID-19 cases or those employed by companies that complied with COVID-19 quarantine regulations. This is a surprising result; that is, the spread of COVID-19 is prevalent, but this does not directly lead to the use of apps. Hence, understanding people's needs in the current situation is essential. The current findings suggest that a focus on promoting and distributing the service in view of the high intention of use by those with underlying diseases and those who have used COVID-19-related apps should be prioritized. In addition, the app should be promoted and distributed intensively in hospitals or health centers wherein people with underlying diseases may be easily accessible. It would also be beneficial to include a function that recommends other apps over existing apps so that various apps can be 
exposed to active prospective users. Furthermore, it should be considered that many people reported that they do want to use apps to overcome the COVID-19 pandemic.

COVID-19-related apps developed and used in South Korea ranged from those providing information to those used for symptom management, COVID-19 self-diagnosis, self-route management, mapping of COVID-19 cases, and reporting of COVID-19 confirmed cases. Based on the information needed at present, the COVID-19-related information app was found to be faithful to its function. As the COVID-19 pandemic continues, the development and use of GPS- and QR-based self-movement management and mapping of COVID-19 case services are needed. However, as mentioned earlier, these apps still have privacy issues. In addition, according to existing studies, the development ratio of Android- and iOS-based apps are similarly developed and used for COVID-19-related apps [12], but in South Korea, COVID-19 apps are mostly based on Android. Thus, a need to develop iOS-based apps for various Korean smartphone users is evident.

Despite the meaningful results discussed thus far, this study has several limitations. First, a total of 1148 survey respondents were analyzed. However, there were only four patients with confirmed COVID-19 among these participants, which is a low rate of $0.3 \%$ of the total respondents. Thus, to obtain more meaningful results, additional samples of COVID-19 confirmed cases should be collected. Second, although there are many COVID-19-related studies, there is limited published literature available. Third, $51.6 \%$ of the survey respondents were employed in white-collar jobs and managerial positions. Thus, occupational biases might have influenced the interpretation of results. Finally, to determine the current status of apps developed in South Korea, we conducted a search on application software downloading services. Two medical informatics professors and two researchers manually organized the app features in four meetings. To improve on this method, future research should apply tools to investigate the apps instead.

Despite these limitations, there are meaningful implications of the study's findings. It was found that the COVID-19 apps may support activities aimed at overcoming the COVID-19 pandemic. However, our findings emphasized how several actions and requirements are necessary to accomplish this aim. Our findings further identified the most essential apps, as well as provided future directions for app development to overcome COVID-19. This study also emphasized the need for information protection to guarantee maximum privacy for users, thus increasing the likelihood of more users. Overall, several insights into the development of apps related to COVID-19 were identified, which can be utilized in future developments and improvements of new and existing apps related to COVID-19.

\section{Acknowledgments}

This research was supported by Basic Science Research Program through the National Research Foundation of Korea (NRF) funded by the Ministry of Education (NRF-2020R1I1A1A01072400).

\section{Authors' Contributions}

MJR is a principal investigator, and was involved in the research design, questionnaire development, interpretation of results, and writing of the manuscript. JP conducted analyses of the results, interpretation of results, and writing of the manuscript. JH and YK were involved in questionnaire development and interpretation of results, and review of COVID-19-related apps and functions developed in South Korea.

\section{Conflicts of Interest}

The corresponding author (MJR) and the first author (JP) are a married couple. There are no competing financial interests.

\section{Multimedia Appendix 1}

COVID-19-related apps in South Korea.

[DOCX File, 2995 KB-Multimedia Appendix 1]

\section{References}

1. Lee D, Lee J. Testing on the move: South Korea's rapid response to the COVID-19 pandemic. Transp Res Interdiscip Perspect 2020 May;5:100111 [FREE Full text] [doi: 10.1016/j.trip.2020.100111] [Medline: $\underline{34171015}$ ]

2. Abeler J, Bäcker M, Buermeyer U, Zillessen H. COVID-19 contact tracing and data protection can go together. JMIR Mhealth Uhealth 2020 Apr 20;8(4):e19359 [FREE Full text] [doi: 10.2196/19359] [Medline: $\underline{32294052}$ ]

3. Wang S, Ding S, Xiong L. A new system for surveillance and digital contact tracing for COVID-19: spatiotemporal reporting over network and GPS. JMIR Mhealth Uhealth 2020 Jun 10;8(6):e19457 [FREE Full text] [doi: 10.2196/19457] [Medline: 32499212]

4. Jonker M, de Bekker-Grob E, Veldwijk J, Goossens L, Bour S, Rutten-Van Mölken M. COVID-19 contact tracing apps: predicted uptake in the Netherlands based on a discrete choice experiment. JMIR Mhealth Uhealth 2020 Oct 09;8(10):e20741 [FREE Full text] [doi: $\underline{10.2196 / 20741]}$ [Medline: $\underline{\text { 32795998] }}$

5. Park S, Choi GJ, Ko H. Information technology-based tracing strategy in response to COVID-19 in South Korea-privacy controversies. JAMA 2020 Jun 02;323(21):2129-2130. [doi: 10.1001/jama.2020.6602] [Medline: 32324202] 
6. Choi J, Lee S, Jamal T. Smart Korea: Governance for smart justice during a global pandemic. Journal of Sustainable Tourism 2020 Jun 10;29(2-3):541-550. [doi: 10.1080/09669582.2020.1777143]

7. Guide on the Installation of Self-quarantine Safety Protection App 2020. Central Disaster and Safety Countermeasures Headquarters, CDSCHQ. URL: http://ncov.mohw.go.kr/upload/ncov/file/202004/1585732793827_20200401181953.pdf [accessed 2021-07-12]

8. Dasgupta N, Lazard A, Brownstein JS. Covid-19 vaccine apps should deliver more to patients. The Lancet Digital Health 2021 May;3(5):e278-e279. [doi: 10.1016/s2589-7500(21)00021-2]

9. Ahmed N, Michelin RA, Xue W, Ruj S, Malaney R, Kanhere SS, et al. A survey of COVID-19 contact tracing apps. IEEE Access 2020;8:134577-134601. [doi: 10.1109/access.2020.3010226]

10. Morley J, Cowls J, Taddeo M, Floridi L. Ethical guidelines for COVID-19 tracing apps. Nature 2020 Jun;582(7810):29-31. [doi: 10.1038/d41586-020-01578-0] [Medline: $\underline{\text { 32467596] }}$

11. Idrees SM, Nowostawski M, Jameel R. Blockchain-based digital contact tracing apps for covid-19 pandemic management: issues, challenges, solutions, and future directions. JMIR Med Inform 2021 Feb 09;9(2):e25245 [FREE Full text] [doi: 10.2196/25245] [Medline: 33400677]

12. Collado-Borrell R, Escudero-Vilaplana V, Villanueva-Bueno C, Herranz-Alonso A, Sanjurjo-Saez M. Features and functionalities of smartphone apps related to COVID-19: systematic search in app stores and content analysis. J Med Internet Res 2020 Aug 25;22(8):e20334 [FREE Full text] [doi: 10.2196/20334] [Medline: 32614777]

13. Luciano F. Mind the app-considerations on the ethical risks of COVID-19 apps. Philos Technol 2020 Jun 13:1-6 [FREE Full text] [doi: 10.1007/s13347-020-00408-5] [Medline: 32837867]

14. COVID-19 Outbreak Status. Webpage in Korean. KOSIS (Korean Statistical Information Service). URL: https://kosis.kr/ covid/covid index.do [accessed 2021-07-12]

15. Coronavirus Infectious Disease-19 Outbreak in Korea (December 6) 2020. Agency KDCaP. URL: http://ncov.mohw.go.kr/ tcmBoardView.do?contSeq=361521\# [accessed 2021-07-12]

16. NAVER. Webpage in Korean. URL: https://www.naver.com/ [accessed 2021-07-12]

17. Kondylakis H, Katehakis DG, Kouroubali A, Logothetidis F, Triantafyllidis A, Kalamaras I, et al. COVID-19 mobile apps: a systematic review of the literature. J Med Internet Res 2020 Dec 09;22(12):e23170 [FREE Full text] [doi: 10.2196/23170] [Medline: 33197234]

18. Ming LC, Untong N, Aliudin NA, Osili N, Kifli N, Tan CS, et al. Mobile health apps on covid-19 launched in the early days of the pandemic: content analysis and review. JMIR Mhealth Uhealth 2020 Sep 16;8(9):e19796 [FREE Full text] [doi: 10.2196/19796] [Medline: 32609622]

19. Venkatesh, Morris, Davis, Davis. User acceptance of information technology: toward a unified view. MIS Quarterly 2003;27(3):425. [doi: 10.2307/30036540]

20. Rho MJ, Kim HS, Chung K, Choi IY. Factors influencing the acceptance of telemedicine for diabetes management. Cluster Comput 2014 Mar 12;18(1):321-331. [doi: 10.1007/s10586-014-0356-1]

21. Rho MJ, Kim H, Sun C, Wang G, Yoon K, Choi IY. Comparison of the acceptance of telemonitoring for glucose management between South Korea and China. Telemed J E Health 2017 Nov;23(11):881-890. [doi: 10.1089/tmj.2016.0217] [Medline: 28598260]

22. Zhang Y, Liu C, Luo S, Xie Y, Liu F, Li X, et al. Factors influencing patients' intentions to use diabetes management apps based on an extended unified theory of acceptance and use of technology model: web-based survey. J Med Internet Res 2019 Aug 13;21(8):e15023 [FREE Full text] [doi: 10.2196/15023] [Medline: 31411146]

23. McKnight P, Najab J. Mann-Whitney U test. The Corsini Encyclopedia of Psychology 2010 Jan 30:1-1. [doi: 10.1002/9780470479216.corpsy0524]

24. Self-quarantine Safety Protection (App). Webpage in Korean. Ministry of the Interior and Safety. URL: https://apps. apple.com/kr/app/ \%ЕC\%9E\%90\%ЕA\%B0\%80\%EA\%B2\%A9\%EB\%A6\%AC\%EC\%9E\%90-\%EC\%95\%88\%ЕC\%A0\%84\%ЕB\%B3\%B4\%ED\%98\%B8/ id1502372537 [accessed 2021-07-12]

25. Zens M, Brammertz A, Herpich J, Südkamp N, Hinterseer M. App-based tracking of self-reported COVID-19 symptoms: analysis of questionnaire data. J Med Internet Res 2020 Sep 09;22(9):e21956 [FREE Full text] [doi: 10.2196/21956] [Medline: 32791493]

26. Mazza MG, De Lorenzo R, Conte C, Poletti S, Vai B, Bollettini I, COVID-19 BioB Outpatient Clinic Study group, et al. Anxiety and depression in COVID-19 survivors: role of inflammatory and clinical predictors. Brain Behav Immun 2020 Oct;89:594-600 [FREE Full text] [doi: 10.1016/j.bbi.2020.07.037] [Medline: 32738287]

27. Hyland P, Shevlin M, McBride O, Murphy J, Karatzias T, Bentall RP, et al. Anxiety and depression in the Republic of Ireland during the COVID-19 pandemic. Acta Psychiatr Scand 2020 Sep;142(3):249-256. [doi: 10.1111/acps.13219] [Medline: 32716520]

28. Lebel C, MacKinnon A, Bagshawe M, Tomfohr-Madsen L, Giesbrecht G. Elevated depression and anxiety symptoms among pregnant individuals during the COVID-19 pandemic. J Affect Disord 2020 Dec 01;277:5-13 [FREE Full text] [doi: 10.1016/j.jad.2020.07.126] [Medline: 32777604] 
29. Salari N, Hosseinian-Far A, Jalali R, Vaisi-Raygani A, Rasoulpoor S, Mohammadi M, et al. Prevalence of stress, anxiety, depression among the general population during the COVID-19 pandemic: a systematic review and meta-analysis. Global Health $2020 \mathrm{Jul}$ 06;16(1):57 [FREE Full text] [doi: 10.1186/s12992-020-00589-w] [Medline: $\underline{32631403}$ ]

30. Choi EPH, Hui BPH, Wan EYF. Depression and anxiety in Hong Kong during COVID-19. Int J Environ Res Public Health 2020 May 25;17(10):3740 [FREE Full text] [doi: 10.3390/ijerph17103740] [Medline: 32466251]

31. Elbay RY, Kurtulmuş A, Arpacioğlu S, Karadere E. Depression, anxiety, stress levels of physicians and associated factors in Covid-19 pandemics. Psychiatry Res 2020 Aug;290:113130 [FREE Full text] [doi: 10.1016/j.psychres.2020.113130] [Medline: 32497969]

32. Labrague L, De Los Santos JAA. COVID-19 anxiety among front-line nurses: Predictive role of organisational support, personal resilience and social support. J Nurs Manag 2020 Oct;28(7):1653-1661 [FREE Full text] [doi: 10.1111/jonm.13121] [Medline: $\underline{\text { 32770780] }}$

33. Liu Z, Han B, Jiang R, Huang Y, Ma C, Wen J, et al. Mental health status of doctors and nurses during COVID-19 epidemic in China. SSRN Preprints. Preprint posted online on March 18, 2020. [doi: 10.2139/ssrn.3551329]

34. Adhikari SP, Meng S, Wu Y, Mao Y, Ye R, Wang Q, et al. Epidemiology, causes, clinical manifestation and diagnosis, prevention and control of coronavirus disease (COVID-19) during the early outbreak period: a scoping review. Infect Dis Poverty 2020 Mar 17;9(1):29 [FREE Full text] [doi: 10.1186/s40249-020-00646-x] [Medline: 32183901]

35. Yong SEF, Anderson DE, Wei WE, Pang J, Chia WN, Tan CW, et al. Connecting clusters of COVID-19: an epidemiological and serological investigation. Lancet Infect Dis $2020 \mathrm{Jul} ; 20(7): 809-815$ [FREE Full text] [doi: 10.1016/S1473-3099(20)30273-5] [Medline: 32330439]

36. Yamamoto K, Takahashi T, Urasaki M, Nagayasu Y, Shimamoto T, Tateyama Y, et al. Health observation app for COVID-19 symptom tracking integrated with personal health records: proof of concept and practical use study. JMIR Mhealth Uhealth $2020 \mathrm{Jul}$ 06;8(7):e19902 [FREE Full text] [doi: 10.2196/19902] [Medline: 32568728]

37. Chan EY, Saqib NU. Privacy concerns can explain unwillingness to download and use contact tracing apps when COVID-19 concerns are high. Comput Human Behav 2021 Jun;119:106718 [FREE Full text] [doi: 10.1016/j.chb.2021.106718] [Medline: 33526957]

38. Ekong I, Chukwu E, Chukwu M. COVID-19 mobile positioning data contact tracing and patient privacy regulations: exploratory search of global response strategies and the use of digital tools in Nigeria. JMIR Mhealth Uhealth 2020 Apr 27;8(4):e19139 [FREE Full text] [doi: 10.2196/19139] [Medline: 32310817]

39. Okereafor K, Adebola O. Tackling the cybersecurity impacts of the coronavirus outbreak as a challenge to internet safety. Int J IT Eng 2020 Feb;8(2).

\section{Abbreviations}

NRF: National Research Foundation of Korea

Edited by C Lovis; submitted 01.04.21; peer-reviewed by S Rostam Niakan Kalhori, K Halttu; comments to author 25.04.21; revised
version received 16.05.21; accepted 17.06.21; published 30.07.21
Please cite as:
Park J, Han J, Kim Y, Rho MJ
Development, Acceptance, and Concerns Surrounding App-Based Services to Overcome the COVID-19 Outbreak in South Korea:
Web-Based Survey Study
JMIR Med Inform 2021;9(7):e29315
URL: $\underline{\text { https://medinform.jmir.org/2021/7/e29315 }}$
doi: $\underline{10.2196 / 29315}$
PMID: $\underline{34137726}$

CJihwan Park, Jinhyun Han, Yerin Kim, Mi Jung Rho. Originally published in JMIR Medical Informatics (https://medinform.jmir.org), 30.07.2021. This is an open-access article distributed under the terms of the Creative Commons Attribution License (https://creativecommons.org/licenses/by/4.0/), which permits unrestricted use, distribution, and reproduction in any medium, provided the original work, first published in JMIR Medical Informatics, is properly cited. The complete bibliographic information, a link to the original publication on https://medinform.jmir.org/, as well as this copyright and license information must be included. 